\title{
ANALYSIS OF CAPACITY FOR IMPLEMENTATION OF TIF PROJECTS FOR ELECTRIC TRANSPORT DEVELOPMENT IN RUSSIAN CITIES
}

\author{
EVGENII LEONTEV, YULIA LEONTYEVA \& IGOR MAYBUROV \\ Ural Federal University, Ekaterinburg, Russian Federation.
}

\begin{abstract}
Cities in Russia are faced with a burning problem of procuring funds for public transit and transport infrastructure projects. The article aims to evaluate the possibility of using Tax Increment Financing (TIF) in various cities of Russia by calculating property tax revenue increments from a TIF project and designating the increments as a protected source of funds for recouping investments in the project. The authors proceed from a hypothesis that it is possible to justify the priority of the city's fiscal capacity for TIF adoption over its land area and the size of its population. The study analyzes a major TIF project that was implemented in the field of public transportation. The outcomes of the project were extrapolated to transport projects in other cities in Russia. Calculations show that the majority of the cities included in the study fit the criteria for TIF projects. The study proves that calculating the projected costs of TIF-funded projects for the development of electric public transport enables the grouping of the cities by potential for TIF project implementation. At the same time, other characteristics of cities, such as the size of population, are not the determinants of such potential. The valuation of TIF potential could serve as a basis for a rapid feasibility study of a TIF project in a city, removing the need for laborious calculations.

Keywords: electric public transport, property tax, tax base, tax increment, tax increment financing, TIF project.
\end{abstract}

\section{INTRODUCTION}

Ensuring the smooth running of public transport in a city is one of the key functions of the municipal administration [1]. The task is closely related to search for funds to finance the operation of municipal public transport and the expansion of the network.

Sources of funds for public transport systems are manifold [2]. First and foremost, it is the public transport operator's revenue from the sale of tickets. In that case, it is the traveler who pays for public transport services. In most cases, however, public transit systems require financing from governments to continue to operate efficiently.

The problem of finding sources of finance for public transport and transport infrastructure projects is extremely acute at the city level in Russia. All too often municipalities lack sufficient revenue to implement modern capital-intensive projects aimed at the development of municipal public transportation networks. This is primarily true for electric public transportation that constitutes a green fast-speed mass transportation option using dedicated lanes, providing a worthy alternative to growing car traffic in municipalities. The lack of a secured budget, dependence on subsidies from regional and municipal authorities, and a low level of interest from private investors hampers the implementation of investment projects in the field of municipal public transport.

As a result, electric public transportation options are only available in the big cities of Russia. There is poor access to electric public transit in the majority of medium-sized and small towns of Russia, which slows down welfare improvement there. 
A globally known financing tool - Tax Increment Financing (TIF) - addresses this very problem. TIF facilitates the implementation of capital-intensive projects, including the ones in the field of municipal public transit, even when no government funds are available.

TIF projects make it possible to radically improve the quality of life and boost economic growth in towns. The existing practice of implementing TIF projects and a considerable amount of research on the issue provide evidence of the positive impact of such projects on municipal economies. The overwhelming majority of TIF projects were implemented in various US towns, whereas in Russia, there has been none. Nor have any studies been conducted in this country to assess the possibility of TIF adoption.

This study aims to assess the possibility of TIF use in various cities of Russia by calculating incremental increases in property tax revenue from TIF projects and designating the increment as a protected source of recouping investments in the project.

There is a hypothesis that it is possible to justify the priority of the fiscal capacity of a city to implement TIF projects over the size of its land area and population. To fulfil this objective, we will analyze one of the biggest TIF projects in the field of public transport and extrapolate the outcomes to the cases of Russian cities. It will also be compared to major public transit projects that were implemented in Russia without TIF use.

\section{TIF PROJECTS: A LITERATURE REVIEW}

TIF is a self-sufficient funding option allowing communities (municipalities) to improve the quality of urban infrastructure by increasing the value of real estate and, therefore, property tax revenue. This type of financing the public good has become widely spread in the United States where the first TIF projects were implemented in California. A considerable body of research has been accumulated that proves the effectiveness of this financing method.

Dye and Merriman [3] reveal the potential of the TIF mechanism. They showed that an infrastructure project in a district causes land and/or property value growth in the neighboring areas and an increase in tax revenue over the established level without higher tax rates. The tax increments generated by the TIF district, including revenue from the infrastructure project itself, are totally or partially redirected to the project operator up until the completion of the project to recoup the initial investments.

Anderson [4] examined the empirical results of TIF adoption in the state of Michigan. The author concluded that the obtained results concur with the theoretically drawn expectations from the projects. Byrne [5], too, confirms a positive effect of TIF projects, while looking at TIF effects at a more localized level.

Man and Rosentraub [6] analyzed such effects of TIF plans as an increase in sales tax revenue and the creation of new jobs. They compared pre-TIF to post-TIF property value changes and came to a positive conclusion about the efficiency TIF and urban redevelopment. Other authors come up with similar results indicating the positive effects of TIF projects. For example, Smith [7, 8] assessed the impacts of TIF plans on residential [7] and commercial [8] properties in the city of Chicago.

Byrne [9] examines municipalities' TIF adoption decision. In particular, the paper examines if municipalities engage in strategic interaction when making the adoption decision and if municipalities use TIF to capture tax revenue from overlapping jurisdictions. The underlying motivation for testing the strategic interaction hypothesis is to determine whether the popularity of TIF is partly the result of competition among neighboring municipalities for private development. The results show that municipalities do engage in strategic interaction in their TIF adoption decision, but do not use TIF to capture revenue from overlapping jurisdictions. 
There is also a study by Dye and Merriman [10], who challenge the strong assumption of the high efficiency of TIF adoption in cities. The authors point to mixed property value trends in the state of Illinois. Merriman, Skidmore, and Kashian [11] observed that such negative outcomes might have been due to certain constraints to TIF site selection. The need to accumulate a sufficient amount of funds for implementing a TIF project could lead to a bias towards the site that could deliver a greater financial yield as opposed to a district in stronger need of investment.

Clark and O'Connor [12] posited that TIF is based on investment implying property value growth, which could lead to controversial outcomes in a far from transparent financial market. Real estate bubbles could result in a market collapse, making it impossible for developers to recoup their investments.

Smolka and Furtado [13] showed that major public transit stations provide a great opportunity for retail and commercial development. Brazil's Belo Horizonte and Porto Alegre benefited from projects that upgraded and clustered real estate zones along public transit lines. At the same time, a similar project in Curitiba resulted in land speculation processes and low-income families were forced out to the urban periphery. Cocconcelli and Medda [14] showed that speculative bubbles in the real estate market could be prevented by performing timely and rapid assessments of property values and through flexible adjustment of property tax rates in case of abrupt changes to the tax base.

Bourassa [15] showed that an increase in property tax rates could cause a backlash from taxpayers. Wrong publicity made about an infrastructure project could also lead to its rejection, one case being the city of Pittsburg.

Gibson [16] validates a number of explanations for the location of TIF districts within a city by estimating Weibull duration models of the time to inclusion in a TIF district for neighborhoods in Chicago. The results suggest that a neighborhood's hazard of inclusion in a TIF district is positively related to neighborhood distress, the presence of Empowerment Zones, and the passage of time and negatively related to a neighborhood's political influence.

Weber [17] draws upon the experience of TIF implementation amid crisis to prove that infrastructure projects that are funded with TIF are not affected by crises. For example, the housing crash of 2007 in the United States had no impact on TIF projects in Chicago and several other American cities.

Dardia [18] investigated TIF use in relationship to property taxes. The author proved that a large portion of the tax revenues considerably facilitates the funding of new facilities through TIF. It was shown [18] that the value placed on redevelopment projects' achievements may outweigh concerns about whether TIFs are heavily subsidized. Nonetheless, it is important to know how much one level of government is subsidizing another so that competing uses for public dollars can be fairly considered. Results in ref. [18] suggest that the existing tax increment system is not an effective way to finance redevelopment. Few projects generate enough increase in assessed value to account for their share of these revenues, and those projects that came closest defined blight broadly and included large amounts of vacant land. Tax incentives can lead cities to designate too many areas as blighted, and if true blight is targeted, an area is unlikely to generate enough revenue to earn the tax increment revenues.

The study by Dardia [18] makes four recommendations to state law-makers that should help to resolve the controversy surrounding redevelopment: (1) the legislature should formally clarify the goals of redevelopment; (2) the definition of blight should be aligned with the goals of redevelopment and should be made more precise; (3) some form of oversight authority should be established to monitor TIF behavior; (4) if the legislature intends 
redevelopment to be self-financing rather than heavily subsidized, the pass-through rate should be increased significantly.

The literature review shows that the bulk of research on TIFs highlight their positive effect on economic development in municipalities. There are a few isolated papers that examine a relationship between the taxation potential of a municipality and its capacity for implementing TIF projects. Moreover, no specific criteria have been identified yet that would help group municipalities by their potential to implement TIF projects.

\section{RESEARCH PROCEDURE}

The research procedure consists of several phases.

In phase one, the experience of implementing a TIF project was analyzed. The case for analysis was selected with consideration for the following factors: (1) whether the project was a success story; (2) the availability of information and previous research on the project; (3) the project should be in the field of transport infrastructure; (4) the size of the investment. Eventually, the Transbay Transit Center Project in San Francisco, the largest transit hub project of the past 20 years was selected.

In phase two, previously obtained estimations of the impact of public transit infrastructure on housing values were used. In authors' earlier works [19], [20], [21], empirical data proving the effect of public transport infrastructure on housing values in Yekaterinburg were obtained. Assessments to forecast increases in the tax base in case of new transit line construction were used. It was assumed that the effect would be identical in other cities of Russia.

A regression equation that describes a model for predicting the cost of housing for Yekaterinburg was used [21]:

$$
\begin{aligned}
Y=- & 102772-3931 \times \mathrm{X} 1+57248 \times \mathrm{X} 2+39815 \times \mathrm{X} 3+20973 \times \mathrm{X} 4+ \\
& 6213 \times \mathrm{X} 5+20450 \times \mathrm{X} 6+33493 \times \mathrm{X} 7 .
\end{aligned}
$$

where $\mathrm{Y}$ is the cost per square meter of housing, in rubles, and the regression coefficients reflect the influence of various factors in the predicted cost per square meter (all coefficients are in relative units); these factors are defined as follows:

$\mathrm{X} 1$ represents the influence of the small size of the apartment.

$\mathrm{X} 2$ represents the influence of the micro district in which the house is located.

$\mathrm{X} 3$ represents the influence of the typical characteristics of the house.

$\mathrm{X} 4$ represents the influence of the year the house was built.

$\mathrm{X} 5$ represents the influence of the material of the walls of the house.

$\mathrm{X} 6$ represents the influence of the distance from home to the nearest metro station.

$\mathrm{X} 7$ represents the influence of the distance from home to the nearest tram station.

To build the model, proposals were selected in the amount of 7,685 ads, from which information was obtained about the main properties of real estate objects. With the help of specialized software MapInfo Professional 2019, four layers of the map of Yekaterinburg were compiled:

1. Processed list of addresses of real estate objects for sale (from the site 'upn.ru') is subjected to automatic geocoding.

2. Metro stations (manual geocoding using web services).

3. Tram stations (manual geocoding using web services).

4. Stations of buses and trolleybuses (the layer is taken from public services 'Open street maps'). 
Using the software utility 'Find the shortest distance' for each property, the distance to the nearest metro station, tram and bus/minibus, or trolleybus was calculated.

To carry out multiple regression analysis, the qualitative criteria were converted into an exposed quantitative scale of ratios. A selection method was used to determine the boundaries of intervals with a single average level of cost per square meter, or the average level of cost per square meter was calculated in the case of quality indicators. The basic level was taken as an indicator as close as possible to the average cost per square meter of real estate in Yekaterinburg.

The coefficient X1 'Small size' was calculated on the basis of the ratio of the total area of an apartment to the number of rooms adopted in the methodology for determining the cadastral value of residential premises.

The coefficient X2 'Micro district' was calculated based on the division of the city of Yekaterinburg into micro districts, which is accepted among realtors (information taken from the website of the Ural Chamber of Real Estate 'www.upn.ru'). The address of each property was assigned to one of the groups corresponding to one or another micro district of Yekaterinburg.

The coefficient X3 'Typical characteristics of a house' was calculated based on the division into apartments with improved layout, full-length apartments (full-family), small-sized apartments (small-family), barrack-type apartments (with wooden walls and ceilings), etc. The average cost per square meter of small apartments footage is taken as the basis.

The coefficient X4 'Year of construction' was calculated based on the gradation for the time intervals of mass development: 1935-1959, 1960-1981, 1982-2007, 2008, and younger. The closest average price per square meter of real estate to the average price in the city was recorded for the late Soviet buildings. Accordingly, the average cost per square meter of this group is taken as a basis, and for the rest of the groups, coefficients are calculated that show the ratio of the average cost per square meter of housing, grouped by year of construction to the base value.

The coefficient X5 'Wall material' was calculated based on the gradation of houses for the most common materials: brick, panel, cinder block, wood, reinforced concrete, monolith, etc. The closest average price per square meter of real estate to the average price in the city was recorded for brick houses. The average cost per square meter of this group is taken as a basis, and for the rest of the groups, coefficients are calculated that show the ratio of the average cost per square meter of housing, grouped by wall material to the base value.

The coefficient X6 'Distance to the metro' was calculated based on the gradation of the influence of the availability of metro stations on the cost of housing. The maximum distance of positive externalities within a radius of 1,500 meters has been set. The basic gradation is the location as far as possible from the metro station.

The coefficient X7 'Distance to tram' was calculated based on the gradation of the influence of the availability of tram stops on the cost of housing. The maximum distance of positive externalities within a radius of 500 meters has been set. For the basic gradation, the location is taken as the most distant from the tram stop.

When analyzing the dependence of the cost per square meter of the real estate object on the proximity to the trolleybus and bus stops, it was not possible to identify a trend that demonstrates the dependence of the value of the appraisal object. The data obtained turned out to be multidirectional [21].

In phase three, information on new projects to build tram routes in a number of Russian cities, including the costs of the projects and the length of the tram lines, was collected. The 
data was used to calculate the ratio of the cost of new tram line construction to property tax revenues in the municipalities. This indicator was calculated using the formula:

$$
\mathrm{R}=\operatorname{Pr} / \mathrm{T} \cdot 100 \%
$$

where $\mathrm{R}$ is the ratio of the cost of construction projects for new tram lines with the receipt of property tax from individuals, in \%; Pr is the initial cost of the tram line construction project, in thousand rubles; and $\mathrm{T}$ is the property tax receipts for the calendar year in the territory of the project implementation, in thousand rubles.

In phase four, the possibility of TIF adoption in various cities of Russia was assessed. To do that, cities that differ in land area, population, and property tax revenues were selected.

To estimate the volume of transit infrastructure construction and possible scale of TIF projects, the percentage ratio of $115 \%$ between the cost of the Transbay Transit Centre in San Francisco and annual property tax revenues was used. Finally, the potential volumes of TIF projects in the field of electric transport that could be implemented in various cities in Russia were forecast.

The possible cost of the TIF of the project (Pc, in thousand rubles) was calculated using the formula:

$$
\mathrm{Pc}=\mathrm{T} \cdot 115 \%
$$

The source of these proceeds of property tax was the official information of the Federal Tax Service on the calculation of this tax by municipalities for 2020. For the purposes of taxation of property of individuals in Russia, the cadastral value of this property is used. The cadastral value is as close as possible to the market value of residential real estate. This cadastral value is entered by the Unified State Register of Real Estate and is periodically revalued for tax purposes.

\section{RESULTS}

\subsection{Case for a TIF project for the construction of a transport infrastructure facility}

Construction of new major transportation facilities funded with incremental revenue from property tax must be supported with sufficient sources of such funding. Future incremental revenue from property tax over a set period must be enough to repay the invested capital. The engagement of the private sector in the development of transit hubs and lines is one of the key advantages of TIF programs.

A typical TIF arrangement includes a concession agreement between the municipal administration and the private investor. The present value of tax revenues generated by the TIF district is fixed as of the start of the project. It is assumed that the TIF project in the district will result in an increase in property and/or land values in the neighboring areas and lead to an increment in tax revenues - with tax rates unchanged. The incremental tax revenues associated with the TIF project, including the revenues generated by the project itself (if any), are redirected by the municipal government to the TIF project budget up until its completion to be used for repaying the initial investments.

Consequently, the potential for TIF implementation depends on the following factors: first of all, the cost of building the transport infrastructure facility; second, the increment in property value to be generated by the future facility; and third, the size of the combined property tax base (revenues from property tax). 
In order to determine the proportions between the cost of a facility and annual property tax revenues, it was considered feasible to assess the implementation of one of the largest new transit hubs that was funded by means of TIF - the Transbay Transit Center in San Francisco, a major multi-modal transit station.

The project masterminded by the Transbay Joint Powers Authority (TJPA) incorporates:

- a regional transit center that will serve 11 transportation systems, including rail, buses, taxies, bicycles, and a network of moving walkways.

- a large rooftop parks.

- shopping space.

- a variety of public amenities.

The designers highlighted a number of positive externalities of the TIF project [22]:

1. some 125,000 new jobs were created (both temporary construction jobs and permanent jobs as the project-boosted economic activity in the area).

2. labor market improvements, thanks to easier commute and accessibility of public transit.

3. tourism development and less car traffic on the roads, which results in emission reduction.

4. gross regional product growth. The project and associated activities are estimated to the generated 87bn dollars in gross regional product by 2030 .

The total cost of phase one works on the project was 2,259.4 million dollars, while property taxes were projected to amount to 1,956 million dollars in FY 2019-2020 [23].

The cost of this successful TIF project is, therefore, $115.51 \%$ of San Francisco's annual property tax revenues. Such comparability is critical because this fiscally important tax will generate a substantial tax increment as a result of property value growth. In the future, this increment will be used as the basis for recouping the funds invested in the TIF project.

\subsection{Analysis of the feasibility of TIF projects in cities in Russia}

The factor of comparability of tax revenue from personal property and the cost of the project is, in the authors' opinion, the key barrier to TIF adoption in Russia. At the same time, Russia does not lag behind a global trend of incremental property value being created by better access to transit infrastructure.

This assumption was earlier substantiated with the study of the case of Ekaterinburg [19]. We obtained empirical data that indicate the effect of public transit infrastructure on the value of housing according to eqn (1). The proximity to a subway station adds the biggest premium to house prices (3-12\%). Tram systems contribute a little less to overall real estate prices (3.2-8.8\%). The revealed relationships according to eqn (1) make it possible to use the obtained data in forecasting future property tax base increases in case of new transit line construction.

Building upon the revealed relationships, the cost of new transit facilities (namely, new tram lines) is estimated. Data from state procurement contracts for construction of new tram lines in various cities of Russia is used (Table 1).

Calculations of the ratio of the cost of projects for the construction of new tram lines with the receipt of property tax of individuals in these municipalities were made according to eqn (2). The data are presented in Table 2. 
Table 1: New tram line projects in cities in Russia.

\begin{tabular}{|c|c|c|c|}
\hline City & Facility & $\begin{array}{l}\text { Cost, } \\
\text { thousand } \\
\text { roubles }\end{array}$ & $\begin{array}{l}\text { Length of } \\
\text { line, } k m\end{array}$ \\
\hline Ekaterinburg & $\begin{array}{l}\text { Ekaterinburg - Verkhnyaya Pyshma } \\
\text { tram line }\end{array}$ & $2,220,098$ & 8.5 \\
\hline Krasnodar & $\begin{array}{l}\text { Tram line along Moskovskaya str. from } \\
\text { Solnechnaya str. to Pyotr Metalnikov } \\
\text { str. }\end{array}$ & 913,843 & 5.5 \\
\hline Samara & $\begin{array}{l}\text { Renovation of tram line from Uritsky } \\
\text { square to Moskovskoye motorway, } \\
\text { including construction of new tram line } \\
\text { from Tashkentskaya str. to the stadium }\end{array}$ & 741,064 & 2.2 \\
\hline $\begin{array}{l}\text { Naberezhnye } \\
\text { Chelny }\end{array}$ & $\begin{array}{l}\text { Construction of tram line from balloon } \\
\text { loop in Syuyumbike avenue along Mira } \\
\text { avenue, Naberezhnochelninsky avenue } \\
\text { to Nizametdinov str. }\end{array}$ & 576,800 & 5.5 \\
\hline Novosibirsk & $\begin{array}{l}\text { Construction of double track tram line } \\
\text { with a stop and a turning loop along } \\
\text { Titov str. In Leninsky district }\end{array}$ & 81,380 & 2.3 \\
\hline
\end{tabular}

Table 2: Cost of tram line projects as a percentage of property tax revenues.

\begin{tabular}{llll}
\hline City & $\begin{array}{l}\text { Cost of transit } \\
\text { facility, thousand } \\
\text { roubles }\end{array}$ & $\begin{array}{l}\text { Property tax } \\
\text { revenues, thousand } \\
\text { roubles }\end{array}$ & $\begin{array}{l}\text { Percentage ratio between } \\
\text { cost of project and revenue } \\
\text { from property tax, \% }\end{array}$ \\
\hline Ekaterinburg & $2,220,098$ & $1,175,148$ & 188.92 \\
Krasnodar & 913,843 & 871,343 & 104.88 \\
Samara & 741,064 & 678,483 & 109.22 \\
Naberezhnye & 576,780 & 285,343 & 202.14 \\
Chelny & & 663,414 & 12.27 \\
Novosibirsk & 81,380 & &
\end{tabular}

It is obvious that the ratios between the cost of construction and tax revenues from personal property that were exhibited by projects implemented in Krasnodar and Samara are similar to that of the Transbay Transit Centre project in San Francisco. This enables a conclusion to be drawn as to the feasibility of TIF adoption in the three Russian cities. The costs of the transport project in Novosibirsk are very low and can be covered through direct budget funding.

The cost of building the Ekaterinburg - Verkhnyaya Pyshma tram line exceeds greatly the ratio between the cost of construction and property tax revenues. It has to be noted, though, 
that the line will connect two municipalities, so the invested funds will have a growth effect on property values in both of them. This allows one to suppose that this project, too, had the potential for being financed through TIF.

The ratio for the Naberezhnye Chelny project indicates that the tax base for personal property tax is insufficient for TIF adoption in transit infrastructure projects.

Proceeding from the obtained ratios between the cost of TIF projects and revenues from personal property tax according to eqn (3) estimations for TIF projects based on the fiscal capabilities of various cities in Russia have been produced. The results are presented in Table 3.

The table shows that Russia's cities vary greatly in terms of their fiscal capacity. Additionally, the estimated values need to be adjusted for varying response of real estate prices to the proximity to public transit infrastructure. That will produce estimated increments in housing values as a result of TIF project implementation. Such data should be empirically obtained for each city. The findings might differ from those in the case of Yekaterinburg [21].

Despite the limited information on the projected tax base increments, practically all cities in the study have sufficient potential to implement capital-intensive projects aimed at creating (renovating) transport infrastructure through TIF.

Table 3 also illustrates the impossibility of assessing the potential of TIF adoption on the basis of traditional criteria for investment decision making, such as the population or the size

Table 3: Characteristics of Russian cities from the perspective of their capability of implementing TIF projects.

\begin{tabular}{lllll}
\hline & $\begin{array}{l}\text { Revenue from } \\
\text { personal property } \\
\text { tax, thousand } \\
\text { roubles }\end{array}$ & $\begin{array}{l}\text { Possible cost of TIF } \\
\text { project, thousand } \\
\text { roubles }\end{array}$ & Population & $\begin{array}{l}\text { Area, } \\
\mathbf{k m}^{2}\end{array}$ \\
\hline Volgograd & 509,056 & 588,011 & $1,008,998$ & 859 \\
Izhevsk & 363,538 & 419,923 & 648,146 & 316 \\
Kazan & $1,062,627$ & $1,227,440$ & $1,257,391$ & 515 \\
Krasnodar & 871,343 & $1,006,488$ & 932,629 & 339 \\
Chelyabinsk & 414,300 & 478,558 & $1,196,680$ & 530 \\
Magnitogorsk & 119,335 & 137,844 & 413,253 & 392 \\
Novokuznetsk & 129,897 & 150,044 & 549,403 & 424 \\
Perm & 760,663 & 878,642 & $1,055,397$ & 803 \\
Moscow & $656,990,199$ & $758,889,379$ & $12,480,481$ & 2561 \\
Novosibirsk & 663,414 & 766,310 & $1,625,631$ & 502 \\
Ekaterinburg & $1,175,148$ & $1,357,413$ & $1,493,749$ & 468 \\
Nizhny & 858,099 & 991,190 & $1,252,236$ & 460 \\
Novgorod & & 783,716 & $1,156,659$ & 541 \\
Samara & 678,483 & 4,734210 & $5,398,064$ & 1439 \\
St Petersburg & $4,098,528$ & 137,046 & 224,630 & 294 \\
Angarsk & 118,644 & 33,385 & 105,531 & 103 \\
Achinsk & 28,902 & & & \\
\hline & & & & \\
\hline
\end{tabular}


of the city. For example, Chelyabinsk and Samara have practically the same populations, yet the potential cost of a transit project funded by TIV would be 1.6 times bigger in Samara than in Chelyabinsk.

The cities of approximately the same size could also differ in terms of TIF project cost: the potential of Krasnodar for TIF implementation is 2.4 times bigger than that of Izhevsk despite being similar by area.

At the same time, the potential costs of TIF projects might be practically identical in cities that have nothing in common on all traditional parameters. This is true for Angarsk and Magnitogorsk, the latter being practically twice as big by population and 30\% bigger in size than Angarsk.

It is, therefore, possible to use estimated costs of TIF projects for grouping cities by potential for TIF implementation. At the same time, other characteristics of cities, such as the size of population or land area, are not the determinants of such potential.

\section{CONCLUSION}

TIF is a mechanism for independent funding by communities (municipalities) of improvements to public transit systems through an increase in real estate value and, consequently, future property tax increments. The incremental tax revenue constitutes a secure source of funds for repaying the private investments contributed to the project.

Calculations that were performed as part of the study showed that the majority of cities in Russia match the criteria that were formulated on the basis of a comparative analysis of a successful TIF project.

The tax potential capability of TIF implementation is irregular and does not correlate with the size of the city's population or its land area. Cities that are not identical exhibit similar potential for TIF adoption. The tax potential of a municipality to implement TIF projects, first and foremost, depends on the size of the existing tax base for property tax. The second major factory is the projected incremental growth in municipal property value driven by the project implementation. These dependencies provide for greater prospects of TIF use as compared to the traditional size-based approach to financing of projects that differentiates between small and medium-sized towns and big cities.

The cost-based approach to assessing the potential for TIF use could serve as a foundation for a rapid feasibility study of a TIF project in a city without performing laborious calculations that will, of course, be necessary at the phase of preparing project documents.

\section{REFERENCES}

[1] Magaril, E., Magaril, R., Panepinto, D., Genon, G., Ravina, M., Trushkova, L. \& Zanetti, M.C., Production and utilization of energy and climate adaptation: Global tasks and local routes. International Journal of Sustainable Development and Planning, 12(8), pp. 1326-1337, 2017. http://dx.doi.org/10.2495/SDP-V12-N8-1326-1337

[2] Leontyeva, Yu.V. \& Mayburov I.A., Theoretical framework for building optimal transport taxation system. Journal of Tax Reform, 2(3), pp. 193-207, 2016. http://dx.doi. org/10.15826/jtr.2016.2.3.024

[3] Dye, R.F. \& Merriman, D.F., The effects of tax increment financing on economic development. Journal of Urban Economics, 47(2), pp. 306-328, 2000. https://doi. org/10.1006/juec.1999.2149

[4] Anderson, J.E., Tax increment financing: municipal adoption and growth. National Tax Journal, 43(2), pp. 155-163, 1990. https://doi.org/10.1086/NTJ41788833 
[5] Byrne, P.F., Determinants of property value growth for tax increment financing districts. Economic Development Quarterly, 20(4), pp. 317-329, 2006. https://doi. org/10.1177/0891242406291540

[6] Man, J.Y. \& Rosentraub, M.S., Tax increment financing: municipal adoption and effects on property value growth. Public Finance Review, 26(6), pp. 523-547, 1998. https:// doi.org/10.1177/109114219802600601

[7] Smith, B.C., The impact of tax increment finance districts on localized real estate: evidence from Chicago's multifamily markets. Journal of Housing Economics, 15(1), pp. 21-37, 2006. https://doi.org/10.1016/j.jhe.2006.02.003

[8] Smith, B.C., If you promise to build it, will they come? The interaction between local economic development policy and the real estate market: evidence from tax increment finance districts. Real Estate Economics, 37(2), pp. 209-234, 2009. https://doi. org/10.1111/j.1540-6229.2009.00240.x

[9] Byrne, P.F., Strategic interaction and the adoption of tax increment financing. Regional Science and Urban Economics, 35(3), pp. 279-303, 2005. https://doi.org/10.1016/j.regsciurbeco.2004.04.002

[10] Dye, R.F. \& Merriman, D.F., The effect of tax increment financing on land use. The Property Tax, Land Use and Land Use Regulation, ed. D. Netzer, Edward Elgar Publishing, chapter 2, pp. 37-61, 2003.

[11] Merriman, D.F., Skidmore, M.L. \& Kashian R.D., Do tax increment finance districts stimulate growth in real estate values? Real Estate Economics, 39(2), pp. 221-250, 2011. https://doi.org/10.1111/j.1540-6229.2010.00294.x

[12] Clark, G.L. \& O'Connor, K., The informational content of financial products and the spatial structure of the global finance industry. Spaces of Globalization: Reasserting the Power of the Local, ed. K.R. Cox, Guilford Press: New York, pp. 89-114, 1997. https:// ora.ox.ac.uk/objects/uuid:b4eaf96d-6133-4fc7-ba5d-0af11bd2c994

[13] Smolka, M.O. \& Furtado, F., Mobilising land value increments for urban development: learning from the Latin America experience. IDS Bulletin, 33(3), pp. 84-89, 2002. https://doi.org/10.1111/j.1759-5436.2002.tb00027.x

[14] Cocconcelli, L. \& Medd, F.R., Boom and bust in the Estonian real estate market and the role of land tax as a buffer. Land Use Policy, 30(1), pp. 392-400, 2012. https://doi. org/10.1016/j.landusepol.2012.04.007

[15] Bourassa, S.C., The political economy of enacting land value taxation. Land Value Taxation, eds. R.F. Dye \& R.W. England, The Lincoln Institute of Land Policy: Bolton, 2009. https://www.lincolninst.edu/sites/default/files/pubfiles/land-value-taxation-chp.pdf

[16] Gibson, D., Neighborhood characteristics and the targeting of tax increment financing in Chicago. Journal of Urban Economics, 54(2), pp. 309-327, 2003. https://doi. org/10.1016/S0094-1190(03)00061-5

[17] Weber, R., Selling city futures: the financialization of urban redevelopment policy. Economic Geography, 86(3), pp. 251-274, 2010. https://doi.org/10.1111/j.19448287.2010.01077.x

[18] Dardia, M., Subsidizing Redevelopment in California. Public Policy Institute of California: San Francisco, 1998. https://www.ppic.org/publication/subsidizing-redevelopment-in-california/

[19] Leontev, E.V. \& Mayburov, I.A., Assessment of the impact of public transport accessibility on the value of urban residential real estate. Journal of Applied Economic Research, 20(1), pp. 62-83, 2021. https://doi.org/10.15826/vestnik.2021.20.1.003 
[20] Leontev, E.V. \& Leontyeva, Yu.V., Individual property tax to fund public transport. Journal of Tax Reform, 7(1), pp. 6-19, 2021. https://doi.org/10.15826/jtr.2021.7.1.087

[21] Leontev, E.V. \& Mayburov, I.A., Realization of the benefits from the functioning of municipal electric transport in the taxation of the property of individuals. Journal of Applied Economic Research, 20(3), pp. 406-427, 2021. https://doi.org/10.15826/vestnik.2021.20.3.017

[22] Transbay Transit Center: Key Investment in San Francisco's Future as a World Class City. Seifel Consulting the Concord Group, June 14, 2012. https://www.tjpa.org/ uploads/2012/06/TJPA_BenefitAnalysis_61412_full.pdf

[23] Expenditures and Revenues vs. Budget. Actual Expenditures vs. Budget, Fiscal Year 2019-20. https://sfgov.org/scorecards/finance/expenditures-and-revenues-vs-budget 